ЄВРОПЕЙСЬКІ МОДЕЛІ ДЕРЖАВНОЇ ПОЛІТИКИ

У СФЕРІ СОЦІАЛЬНОЇ АДАПТАЦІЇ ТА СОЦІАЛЬНОГО ЗАХИСТУ УЧАСНИКІВ БОЙОВИХ ДІЙ

\title{
EUROPEAN MODELS OF PUBLIC POLICY \\ IN THE FIELD OF SOCIAL ADAPTATION AND SOCIAL DEFENSE OF PARTICIPANTS OF BATTLE ACTIONS
}

\begin{abstract}
У статті досліджено сучасний стан та проблематику формування й реалізації державної політики у сорері соціальної адаптації та соціального захисту учасників бойових дій Великобританії та Хорватії.

Автором визначено сутність роботи державних інституцій, що відповідають за соціальний захист, адаптацію та реабілітацію учасників бойових дій. Узагальнено досвід роботи виконавчого органу чентральної влади Великобританії, який відповідальний за пенсійне та соціальне забезпечення воїнів Збройних Сил Королівства, ветеранів та членів їхніх сімей - "Veterans UK" як підрозділу Міністерства оборони. Встановлено, що "Veterans UK" надає широкий спектр послуг (визначення, призначення та виплата компенсацій) для військовослужбовців та ветеранів у рамках Програми компенсації військовослужбовцям та пенсійного забезпечення інвалідів війни, вдів (вдівців) військовослужбовців, що загинули на війні, учасників бойових дій Великобританії.

Акцентовано увагу на державних та регіональних програмах соціального захисту учасників бойових дій у Хорватії. Начіональна програма соціально-психологічної та медичної допомоги учасникам та жертвам Вітчизняної війни 1991-1995 рр., Другої світової війни і місій з підтримання миру в Хорватії включає в себе психологічну та медичну допомогу учасникам та жертвам війни $і \epsilon$ корисним досвідом для використання в Україні. Зазначено, що в кожному адміністративно-територіальному окрузі Хорватії розміщений центр соціально-психологічної допомоги, що надає соціальну та юридичну допомогу, пов'язану із процедурою отримання та реалізації прав, передбачених Законом «Про права ветеранів Хорватськоі вітчизняної війни та членів їх сімей». Зазначено, що Міністерство у справах ветеранів війни реалізує програму професійної підготовки та працевлаштування хорватських ветеранів та дітей загиблих, безвісно відсутніх учасників війни.

Визначено основні напрями соціальної політики цих країн та державні механізми у проведенні соціальної політики по відношенню до учасників бойових дій.
\end{abstract}

Ключові слова: соціальний захист, Великобританія, Хорватія, вдови, учасники бойових дій, державна політика.

The article investigates the current state and problems of the formation and implementation of state policy in the field of social adaptation and social protection of participants of hostilities of Great Britain and Croatia.

The author defines the essence of the work of state institutions responsible for social protection, adaptation and rehabilitation of participants of hostilities. The experience of working for the UK Central Authority, which is responsible for pension and social security for the veterans of the United Kingdom Armed Forces, veterans and their families - "Veterans UK", as a unit of the Ministry of Defense, is generalized. It is established that Veterans UK provides a wide range of services (identification, assignment and payment of compensation) for servicemen and veterans under the War Veterans and Disabled Persons Disabled War Veterans (widows) War Veterans Participants Program.

Emphasis is placed on national and regional social protection programs for combatants in Croatia. The National Program of Social Psychological and Medical Assistance to Participants and Victims of the Patriotic War 1991-1995, World War II and Peacekeeping Missions in Croatia includes psychological and medical assistance to war participants and victims and is a useful experience for use in Ukraine. It is noted that in each administrative and territorial district of Croatia there is a center for social and psychological assistance providing social and legal assistance related to the procedure for obtaining and exercising the rights stipulated by the Law on the Rights of Veterans of the Croatian Patriotic War and Members of Their Families. It is noted that the Ministry of War Veterans is implementing a program for the vocational training and employment of Croatian veterans and children of war victims who are missing.

The basic directions of social policy of these countries and state mechanisms in conducting social policy towards the participants of hostilities are defined.

Key words: social protection, United Kingdom, Croatia, widows, combatants, public policy. Інститут підготовки кадрів Державної служби зайнятості України

Постановка проблеми. Агресія РФ на Сході України породила нові соціальні проблеми, що виникають після повернення бійців української армії, правоохоронних органів, добровольчих батальйонів після бойових дій. Вони потребують від держави соціального захисту (особливо ті, хто отримав поранення, контузії, став інвалідом), допомоги в соціальній адаптації до нових мирних умов життя, а часто і соціальної реабілітації. На думку науковця
П. Ворони, «будь-яка людина, яка повернулась із зон збройного конфлікту, може мати небажані спогади про війну <...> Ці спогади й емоції можуть бути настільки реалістичними, що людині здається, ніби вона знову в зоні військових дій» $[1$, с. 50] У багатьох з цих бійців може бути посттравматичний синдром (ПТРС), який не сприяє адаптації учасників бойових дій (УБД) до мирних умов. Вони зовсім по-іншому відчувають навколишній світ, у багатьох з них 
виникає загострене почуття справедливості, вини перед загиблими побратимами, агресія до тих, хто там не був і не виконав свій патріотичний і військовий обов'язок. Держава в цих умовах має оточити їх соціальним захистом і повагою та турботою з боку суспільства.

Багато країн світу напрацювали досвід соціального захисту УБД та допомоги у подоланні ПТРС, який варто дослідити для використання в Україні [2].

Аналіз останніх досліджень та публікацій. Наукові дослідження щодо формування моделі державної політики у сфері соціального захисту УБД є актуальними для багатьох науковців. Серед дослідників проблематики соціального захисту та адаптації УБД такі вчені, як С. Ветлицький, П. Ворона, О. Кондратенко, М. Кравченко, С. Кучер, В. Шевченко, М. Шевченко, О. Числіцька, Ю. Ярошок та інші. У дослідженні К. Пенькової наведено кращі світові практики соціального захисту УБД. Зазначаємо, що українське суспільство потребує досліджень соціальної адаптації та реабілітації УБД у сфері державної політики, а особливо у частині використання досвіду зарубіжних моделей соціального захисту УБД.

Мета статті - провести дослідження особливостей європейських моделей (на прикладі Великобританії та Хорватії) формування та реалізації державної політики у сфері соціальної адаптації та захисту учасників бойових дій.

Виклад основного матеріалу. Свого роду еталоном соціального захисту УБД на європейському континенті є Великобританія, яка вже кілька століть як створила систему соціального захисту військовослужбовців, що служили Королівству. У країні виконавчим органом, який відповідальний за пенсійне та соціальне забезпечення воїнів Збройних Сил Королівства, ветеранів та членів їхніх сімей, $€$ орган під назвою "Veterans UK", що $€$ підрозділом Міністерства оборони і утворився 2014 року внаслідок злиття Агентства у справах військовослужбовців і ветеранів та Служби 3 надання послуг оборонного призначення [9]. "Veterans UK" відповідальний за надання широкого спектру послуг (визначення, призначення та виплата компенсацій та пенсій) для військовослужбовців та ветеранів у рамках Програми компенсації військовослужбовцям, Програм пенсійного забезпечення інвалідів війни та пенсійного забезпечення вдів та вдівців військовослужбовців, що загинули на війні, й пенсійного забезпечення учасників бойових дій. Виплати компенсацій за Програмою пенсійного забезпечення УБД здійснюються щодо травм, хвороб чи смерті, що стали результатом участі у бойових діях до 5 квітня 2005 року.
Компенсація за програмою здійснюється у двох основних формах: одноразова виплата та пенсія, що виплачується кожного тижня або кожного місяця. Розмір виплати залежить від того, наскільки травма чи хвороба вплинула на працездатність військовослужбовця, і не залежить від рівня його доходів. Для визначення ступеня серйозності поранення, травми чи захворювання медичними експертами аналізується інформація, надана заявником. Ступінь втрати працездатності розраховується у відсотковому значенні. Якщо інвалідність оцінюється менш ніж у 20\% (наприклад, втрата пальця), заявник має право на одноразову виплату, якщо більше ніж 20\% - призначається регулярна пенсія.

Для подання заяви на отримання компенсації за цією програмою немає часових обмежень. Відповідно до Програми компенсації військовослужбовцям компенсація надається за травми, хвороби або загибель військовослужбовця, що брав участь у бойових діях з 6 квітня 2005 року. Компенсація за програмою здійснюється у вигляді: одноразової виплати; додаткової виплати; гарантованих регулярних виплат, що виплачуються до кінця життя; оплати витрат на лікування [10].

Заява на отримання компенсації має бути подана не пізніше 7 років після більш ранньої з таких подій: дата інциденту, що призвів до травми чи хвороби; дата, коли служба в збройних силах призвела до ускладнення травми чи хвороби, отриманої поза службою; якщо конкретну дату виникнення травми чи хвороби встановити не вдалося - дата звернення за медичною допомогою; дата звільнення із збройних сил [4].

Для того щоб отримати виплату чи компенсацією за будь-якою з програм, необхідно надіслати заяву відповідної форми безпосередньо у "Veterans UK". Далі адміністративний персонал органу починає збір інформації про несення особою військової служби або участь у воєнних діях, які, за словами заявника, призвели до інвалідності. У разі необхідності вони зв'язуються із заявником для уточнення необхідної інформації. Після збору усіх даних справа передається медичним експертам - лікарям, які працюють на "Veterans UK".

Лікарі розглядають медичнучастину заявки і у разі виникнення питань можуть:

1) вимагати проходження заявником медичного огляду;

2) отримати звіт лікаря, на обліку у якого перебуває заявник;

3) отримати інформацію з медичних закладів, в яких лікувався заявник; 
4) вимагати проходження заявником аудіометричного огляду, якщо підставою його звернення є набута внаслідок несення служби глухота [5].

Після збору необхідної інформації про стан здоров'я заявника лікарі оцінюють його у відсотковому значенні, де 0\% - це цілком здоровий. Лікарі також визначають, чи є вади та хвороби набутими внаслідок служби та чи впливає ï наявність на теперішній стан здоров'я. За результатом експертизи лікарі видають висновок. Також слід додати, що експертизи бувають проміжними (якщо лікар переконаний, що стан здоров'я заявника може покращитись чи погіршитись найближчим часом, він може призначити повторну експертизу через певний період часу, наприклад через рік) та остаточними, результати яких можуть підлягати перегляду за ініціативою заявника [5]. Програма пенсійного забезпечення вдів та вдівців військовослужбовців передбачає виплату коштів вдовам та вдівцям (в тому числі, співмешканцям загиблих військовослужбовців, які не перебували у зареєстрованому шлюбі, але спільно проживали) військовослужбовців, які загинули під час бойових дій, перебуваючи на службі в збройних силах, до 6 квітня 2005 року. Вдови осіб, які загинули після 6 квітня 2005 року, можуть отримати компенсацію в рамках Програми компенсації військовослужбовцям [11]. Пенсія вдови може складатись з кількох елементів, залежно від конкретних умов. Вона може включати:

- базову пенсію, яка не оподатковується і виплачується дружині, чоловіку, партнеру по офіційно зареєстрованому одностатевому шлюбу чи співмешканцю, який проживав із загиблим;

- додаткова пенсія (у разі, якщо військовослужбовець був звільнений зі збройних сил до 1973 року);

- податкова пільга для осіб похилого віку, яким виплачується пенсія вдови, після досягнення ними віку 65 років, що зростає по досягненню віку 70 і 80 років;

- дотація на оренду житлового приміщення, яка виплачується особам, які отримують пенсію вдови та мають на утриманні неповнолітню дитину;

- тимчасова допомога, яка виплачується вдовам інвалідів війни після їх смерті; її розмір встановлюється на основі пенсії інваліда війни;

- витрати на поховання - особа, відповідальна за організацію поховання, має право на компенсацію витрат впродовж 3 місяців після дати похорону [12].

Варто підсумувати, що у війську Великобританії військовослужбовець на випадок тра- гедії має всі гарантії щодо допомоги держави як йому, так і його родині [2, с. 3-6].

У Хорватії соціальне забезпечення учасників війни та членів їхніх родин реалізується через спеціальний виконавчий орган, створений у 2011 році - Міністерство у справах ветеранів війни. До 2011 року усі питання, пов'язані з правовим статусом і соціальним забезпеченням інвалідів Хорватської вітчизняної війни (1991-1995рр.), Другої світової війни та членів їхніх сімей, належали до відання Міністерства у справах сім'ї, ветеранів та солідарності між поколіннями, створеного у 2003 році.

Військові дії на території держави мали місце не так давно - під час Хорватської вітчизняної війни (війни за незалежність Хорватії) 1991-1995 рр., і кількість ветеранів війни є доволі великою - станом на 30.04.2016 року реєстр військових ветеранів нараховував 505221 особу, що становить практично 12\% населення країни [3].

У 2004 році був прийнятий Закон «Про права ветеранів Хорватської вітчизняної війни та членів їхніх сімей», що регулює права ветеранів війни та членів їхніх родин. Закон «Про права ветеранів Хорватської вітчизняної війни та членів їхніх сімей» передбачає три основних статуси громадян, що мають право на державну допомогу: ветерани війни, інваліди війни та члени їхніх сімей. Ветерани війни мають право на: охорону здоров'я; пенсійне страхування (право на пенсію за віком, право на отримання пенсії 3 інвалідності, право на мінімальну пенсію тощо); отримання допомоги на дітей; працю; житло; інші права [13].

Тобто ветерани війни мають такі ж права, як і усі громадяни відповідно до Конституції. Що стосується соціальної допомоги ветеранам, то отримання такого статусу передбачає ряд інших прав. Відповідно до статті 5 інвалідом війни вважається особа, організм якої зазнав шкоди принаймні на 20\% внаслідок ран чи травм, отриманих під час захисту суверенітету Хорватії або в результаті утримання в якості військовополоненого; або внаслідок загострення чи виникнення захворювання через вищезазначені причини [13].

Такі особи мають право на: оформлення статусу інваліда; отримання спеціальної допомоги; отримання допомоги по догляду; отримання протезно-ортопедичної допомоги; відшкодування дорожніх витрат.

Члени сім'ї загиблих або безвісно відсутніх ветеранів вітчизняної війни (дружина / чоловік, співмешканець, шлюбні та позашлюбні діти, прийомні діти, батьки, вітчим / мачуха або усиновлювачі) на основі матеріальних потреб мають право на: спеціальну допомогу; отри- 
мання допомоги по догляду; відшкодування вартості поховання.

Національна програма соціально-психологічної та медичної допомоги учасникам та жертвам Вітчизняної війни 1991-1995рр., Другої світової війни і місій з підтримання миру включає в себе психологічну та медичну допомогу учасникам та жертвам війни. Основною довгостроковою метою Національної програми є підвищення загальної якості життя і забезпечення повної психосоціальної реінте- грації всіх учасників і жертв війни за незалежність, а також учасників Другої світової війни, військових і цивільних інвалідів другої світової війни і членів їх сімей та осіб, які загинули під час виконання військових і поліцейських службових обов'язків в іноземній державі в рамках місій ООН, НАТО і ЄС, та членів їх сімей [6].

На місцевому рівні програма реалізується в 21 окрузі; в кожному окрузі розміщений центр соціально-психологічної допомоги. Крім надання психосоціальної допомоги, цен-

\section{Розмір пенсії вдови (вдівця) військовослужбовця, що загинув внаслідок бойових дій (2015-2016) [8]}

\begin{tabular}{|c|c|}
\hline \multicolumn{2}{|l|}{ Пенсія вдови (вдівця) офіцера } \\
\hline Пенсія вдови (вдівця) першого або другого лейтенанта армії & щорічно \\
\hline Вдова (вдівець) старше 40 років або до 40 років з дітьми & $£ 7130$ (близько 260 тис. грн.) \\
\hline Вдова (вдівець) до 40 років без дітей & $£ 1958$ \\
\hline Пенсія вдови (вдівця) капітана армії щорічно & щорічно \\
\hline Вдова (вдівець) старше 40 років або до 40 років з дітьми & $£ 7160$ \\
\hline Вдова (вдівець) до 40 років без дітей £2226 & $£ 2226$ \\
\hline Пенсія вдови (вдівця) майора армії & щорічно \\
\hline Вдова (вдівець) старше 40 років або до 40 років з дітьми & $£ 7187$ \\
\hline Вдова (вдівець) до 40 років без дітей & $£ 2496$ \\
\hline Пенсія вдови (вдівця) підполковника армії & щорічно \\
\hline Вища ставка (лише для учасників війни1914 року) & $£ 7255$ \\
\hline Стандартна ставка & $£ 7241$ \\
\hline Пенсія вдови (вдівця) полковника армії & щорічно \\
\hline Вища ставка (лише для учасників війни 1914 року) & $£ 7279$ \\
\hline Стандартна ставка & $£ 7241$ \\
\hline Пенсія вдови (вдівця) бригадного генерала армії & щорічно \\
\hline Вища ставка (лише для учасників війни 1914 року) & $£ 7447$ \\
\hline Стандартна ставка & $£ 7430$ \\
\hline Пенсія вдови (вдівця) генерал-майора армії & щорічно \\
\hline Вища ставка (лише для учасників війни 1914 року) & $£ 7589$ \\
\hline Стандартна ставка & $£ 7499$ \\
\hline Пенсія вдів (вдівців) військовослужбовців інших рангів & щомісяця \\
\hline Вдова (вдівець) старше 40 років або до 40 років з дітьми & $£ 135,15$ \\
\hline Вдова (вдівець) до 40 років без дітей & $£ 32,37$ (близько 1180 грн.) \\
\hline
\end{tabular}

Розмір пенсії осіб, що знаходились на утриманні

Таблиця 2 загиблого військовослужбовця (2015-2016) [8]

\begin{tabular}{|l|c|c|}
\hline \multicolumn{1}{|c|}{ Пенсії у разі втрати годувальника } & $\begin{array}{c}\text { Сім'я } \\
\text { офіцера } \\
\text { (щорічно) }\end{array}$ & $\begin{array}{c}\text { Сім'я військовослужбовців } \\
\text { інших рангів (щомісячно) }\end{array}$ \\
\hline $\begin{array}{l}\text { Особи, які проживали із загиблим } \\
\text { у незареєстрованому шлюбі } \\
\text { Перша дитина }\end{array}$ & $£ 6930$ & $£ 132,80$ \\
\hline Інші діти & $£ 1265$ & $£ 24,25$ \\
\hline Доросла дитина-інвалід & $£ 1385$ & $£ 26,55$ \\
\hline
\end{tabular}


три надають юридичну допомогу, пов'язану із процедурою отримання та реалізації прав, передбачених Законом «Про права ветеранів Хорватської вітчизняної війни та членів їх сімей». Також центри надають інформацію про програми та проекти, які реалізуються Міністерством ветеранів війни. Крім цього, Міністерство у справах ветеранів війни реалізує програму професійної підготовки та працевлаштування хорватських ветеранів та дітей загиблих, затриманих або безвісно відсутніх учасників війни [7].

Висновки. Державна політика соціального захисту учасників бойових дій в Україні потребує удосконалення та використання елементів досвіду зарубіжних країн щодо забезпечення опіки держави у разі виникнення трагічних випадків серед УБД на лінії зіткнення. У Великобританії, за сотні років її історії спостерігаємо традицію гарантованого великого рівня соціальних виплат, які виплачуються державою щорічно або щомісячно. Хорватія, пройшовши свою Вітчизняну війну (по суті війну за незалежність), маючи майже півмільйонну армію УБЧ, зуміла належним чином організувати їм соціальний захист. Досвід Хорватії особливо повчальний для України в частині законодавчого супроводу соціального захисту УБД та механізмів його забезпечення у виконавчій владі через національні та регіональні програми. Використання світового досвіду соціального захисту УБД сприятиме суспільній стабільності та уникненню соціальної напруги в Україні.

\section{ЛІТЕРАТУРА:}

1. Ворона П.В., Ворона Л.І. Посттравматичний синдром, викликаний зоною АТО, та особливості його подолання: педагогіко-психологічні аспекти. Імідж сучасного педагога. 2016. № 9 (168), С. 49-53.

2. Пенькова К. Соціальний захист учасників бойових дій. Кращі практики Інформаційна довідка, підготовлена Європейським інфрормаційно-дослідницьким центром на запит народного депутата України. URL: http://euinfocenter.rada.gov.ua/uploads/ documents/28938.pdf.

3. Broj branitelja u Registru stalno raste i sad ih je 505 tisuća. URL: http://www.tportal.hr/vijesti/ hrvatska/427360/Broj-branitelja-u-Registru-stalnoraste-i-sad-ihje-505-tisuca.html.

4. Claiming for Illness, Injury or Disease. Ministry of Defence. 2016. URL: https://www.gov.uk/government/ uploads/system/uploads/attachment_data/ file/330719/ Vetera nsUK_AFCS_WPS_Leaflet1.pdf.

5. How we decide who receives a War Disablement Pension. Veterans UK. 2014. URL: https://www.gov.uk/ government/uploads/system/uploads/attachment_data/ file/504507/Leaflet11_proof.pdf.

6. Nacionalni program psihosocijalne i zdravstvene pomoći. URL: https:// branitelji.gov.hr/nacionalni-program-psihosocijalne-i-zdravstvene-pomoci/863.

7. Program stručnog osposobljavanja i zapošljavanja URL: https://branitelji. gov.hr/program-strucnog-osposobljavanja-i-zaposljavanja/870.

8. Rates of War Pensions and allowances 2015 2016 // Veterans UK. 2015. URL: https://www.gov.uk/ government/uploads/system/uploads/attachment_data/ file/ 504505/Vetera ns_UK_Leaflet_9.pdf.

9. Service Personnel and Veterans Agency. URL: https://www.gov.uk/ government/organisations/service-personnel-and-veterans-agency.

10. The Armed Forces and Reserve Forces Compensation Scheme Order (AFCS) 2011 in force from 6 April 2015 SI 2011/517 as amended by SIs 2011/2552, 2012 /1573, 2013/436, 2014/412, 2015/413. URL: http://www.infolaw.co.uk/mod/docs/AFCS-201504-06.pdf.

11. War Widow(er) Pension. URL: https://www.gov.uk/warwidow-pension.

12. War Pension Scheme: what you need to know. Veterans UK. 2016. URL: https://www.gov.uk/government/publications/war-pension-scheme/war-pensionscheme-what-you-need-to-know.

13. Zakon o pravima hrvatskih branitelja iz Domovinskog rata i članova njihovih obitelji URL: http://www.zakon.hr/z/325/Zakon-o-pravima-hrvatskihbraniteljaiz-Domovinskog-rata-i-\%C4\%8Dlanovanjihovih-obitelji. 